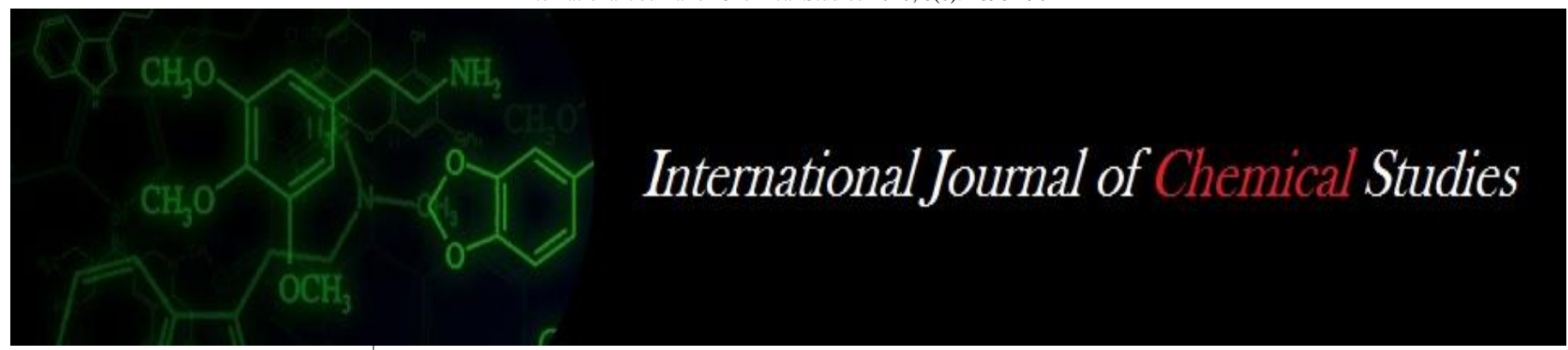

P-ISSN: 2349-8528

E-ISSN: 2321-4902

www.chemijournal.com

IJCS 2020; 8(6): 1898-1901

(C) 2020 IJCS

Received: 06-09-2020

Accepted: 13-10-2020

\section{KK Mourya}

ICAR-National Bureau of Soil

Survey and Land Use Planning,

Regional Centre, Jorhat, Assam,

India

\section{TJ Purakayastha}

ICAR-Indian Agricultural

Research Institute, New Delhi,

India

N Ahmed

ICAR-Indian Agricultural

Research Institute, New Delhi,

India

\section{S Kumar}

ICAR-Indian Agricultural Research Institute, New Delhi,

India

\section{B Chakrabarti}

ICAR-Indian Agricultural

Research Institute, New Delhi, India

\section{B Ramakrishnan}

ICAR-Indian Agricultural

Research Institute, New Delhi, India

\section{K Husain}

Chandra Shekhar Azad

University of Agriculture and

Technology, Kanpur, Uttar

Pradesh, India

N Ravisankar

ICAR-Indian Institute of

Farming System Research,

Modipuram, Meerut, Uttar

Pradesh, India

\section{Effect of long term manuring and fertilization on soil aggregation under rice-wheat cropping system in an Inceptisol}

\author{
KK Mourya, TJ Purakayastha, N Ahmed, S Kumar, B Chakrabarti, B \\ Ramakrishnan, K Husain and N Ravisankar
}

DOI: https://doi.org/10.22271/chemi.2020.v8.i6aa.11044

\begin{abstract}
The long-term effect of manuring and fertilization on aggregate distribution and aggregate associated C was studied under the rice-wheat cropping system in an Inceptisol of the upper Indo-Gangetic plain. Eight treatments from the long term experiment were chosen for this study: control (T1), $100 \%$ NPKfertilizer (T2), 50\% NPK- fertilizer + $50 \%$ N-FYM (T3), 75\% NPK + 25\% N-FYM (T4) and 50\% NPK $+50 \%$ N-Wheat straw (WS) (T5), $75 \%$ NPK $+25 \% \mathrm{~N}-\mathrm{WS}(\mathrm{T} 6), 50 \% \mathrm{NPK}+50 \% \mathrm{~N}$-Green manure (GM) (T7) and 75\% NPK $+25 \%$ N-GM (T8). The results revealed that application of balanced chemical fertilizer alone or in conjunction with FYM, WS or GM favoured the soil aggregation and C buildup in the soil. Highest \% water stable macro-aggregates (WSMA) $(50.49 \%)$ and mean weight diameter (MWD) $(0.85 \mathrm{~mm})$ were resulted under T3 $(50 \% \mathrm{NPK}+50 \% \mathrm{~N}-\mathrm{FYM})$. Macro-aggregate associated C (MA-C) and micro-aggregate associated $\mathrm{C}(\mathrm{mA}-\mathrm{C})$ were increased by 48.7 and $126 \%$ respectively over control under T6 $(75 \% \mathrm{NPK}+25 \% \mathrm{~N}-\mathrm{WS})$. Glomalin content was positively related to the stability of aggregates as indicated by the strong correlation of MWD with glomalin associated with macroaggregates $(\mathrm{GMA})(\mathrm{r}=0.74 *)$ and glomalin associated with micro-aggregates $(\mathrm{GmA})(\mathrm{r}=0.95 * *)$.
\end{abstract}

Keywords: Aggregation, mean weight diameter, rice-wheat cropping, aggregate associated carbon

\section{Introduction}

The soil aggregation is an important process of soil organic C (SOC) stabilization by providing different degrees of protection from decomposition by microorganisms (Jastrow et al., 1996) ${ }^{[8]}$. Aggregates physically protect the SOC by forming physical barrier between microorganism plus microbial enzymes and their substrates (Six et al., 1999) ${ }^{[15]}$. Aggregates are formed by flocculation, cementation, and the rearrangement of particles (Duiker et al., 2003) ${ }^{[4]}$. Soil organic matter is the major binding agent in the soils which helps in the formation of aggregates (Tisdall and Oades, 1982) ${ }^{[17]}$. Organic materials such as humic matter are involved in the stabilization of micro-aggregates and transient bonding agents (polysaccharides) as well as temporary binding agents (fungal hyphae, fine roots, bacterial cells) related to the formation and stabilization of macro-aggregates. Aggregates are categorized into different size classes based on diameter. Commonly three aggregate size classes are defined as large macroaggregates $(>2 \mathrm{~mm})$, small macro-aggregates $(0.25-2 \mathrm{~mm})$, and micro-aggregates $(0.053-0.25$ $\mathrm{mm})$, respectively. Due to the small structure and micro-sized pores, micro-aggregates tend to be more stable than macro-aggregates and are key factors in storing SOC for the long-term (Six et al., 1998) ${ }^{[14]}$.

Soil aggregation and structure are affected by cultivation under different management practices with or without application of organic and inorganic sources of nutrients for a long period (Sharma and Bhushan, 2001) ${ }^{[13]}$. Formation of water stable aggregates hence C sequestration is influenced by the types of applied organic manures and crop residues (Mandal et al., 2007) ${ }^{[11]}$. It is important to evaluate the soil aggregation and its stability with regard to the organic amendments as it is useful for evaluation of soil properties and $\mathrm{C}$ sequestration. Therefore, in the present study, an attempt was made to examine the long term effect of manuring and fertilization on soil aggregate size distribution and $\mathrm{C}$ associated with macro and micro aggregates.
Corresponding Author: TJ Purakayastha ICAR-Indian Agricultural Research Institute, New Delhi, India 


\section{Materials and Methods \\ Experimental site}

The long term fertilizer experiment was started in 1984 at Crop Research Farm, Chandra Sekhar Azad University of Agriculture and Technology, Kanpur (26 ${ }^{\circ} 58^{\prime}$ N, 80 $34^{\circ}$ 'E, 129 $\mathrm{m}$ above $\mathrm{msl}$ ) representing Central Plain Zone of Uttar Pradesh. The climate of the experimental site is sub-tropical monsoonal with an annual rainfall of about $818 \mathrm{~mm}$ and mean monthly maximum and minimum air temperature of $31.9{ }^{\circ} \mathrm{C}$ and $19.6{ }^{\circ} \mathrm{C}$ respectively, monthly mean relative humidity ranges from $53.5 \%$ to $90.3 \%$. Most of the rains received during Kharif season from July to September. The surface soil $(0-15 \mathrm{~cm})$ of the experimental site was sandy loam in texture with mean particle distribution of $47 \%$ sand, $35 \%$ silt and $18 \%$ clay and was slightly alkaline in reaction $(\mathrm{pH}=8.1)$ and non-saline $\left(\mathrm{EC}=0.18 \mathrm{dS} \mathrm{m}^{-1}\right)$. The initial soil had organic $\mathrm{C}$ $2.4 \mathrm{~g} \mathrm{~kg}^{-1}$, available $\mathrm{N} 83.0 \mathrm{~kg} \mathrm{ha}^{-1}$, available $\mathrm{P}_{2} \mathrm{O}_{5} 6.3 \mathrm{~kg} \mathrm{ha}^{-1}$, and available $\mathrm{K}_{2} \mathrm{O} 82.0 \mathrm{~kg} \mathrm{ha}^{-1}$.

\section{Soil sampling and processing}

Surface soil samples $(0-15 \mathrm{~cm})$ were collected from the treatments comprising of control $\left(\mathrm{T}_{1}\right), 100 \% \mathrm{NPK}$ - fertilizer $\left(\mathrm{T}_{2}\right), 50 \% \mathrm{NPK}$ - fertilizer $+50 \% \mathrm{~N}$-farmyard manure $(\mathrm{FYM})$ $\left(\mathrm{T}_{3}\right), 75 \% \mathrm{NPK}+25 \% \mathrm{~N}-\mathrm{FYM}\left(\mathrm{T}_{4}\right)$ and $50 \% \mathrm{NPK}+50 \% \mathrm{~N}-$ Wheat straw (WS) $\left(\mathrm{T}_{5}\right), 75 \% \mathrm{NPK}+25 \% \mathrm{~N}-\mathrm{WS}\left(\mathrm{T}_{6}\right), 50 \%$ $\mathrm{NPK}+50 \% \mathrm{~N}-$ Green manure $(\mathrm{GM})\left(\mathrm{T}_{7}\right)$ and $75 \% \mathrm{NPK}+$ $25 \% \mathrm{~N}-\mathrm{GM}\left(\mathrm{T}_{8}\right)$. These treatments were imposed only in rice but in wheat all the nutrients were applied through fertilizers at the rate of $120 \mathrm{~kg} \mathrm{~N}, 60 \mathrm{~kg} \mathrm{P}_{2} \mathrm{O}_{5}$ and $60 \mathrm{~kg} \mathrm{~K} 2 \mathrm{O} / \mathrm{ha}$. The recommended dose of NPK for rice for $\mathrm{T}_{2}(100 \%$ NPK) was $120 \mathrm{Kg} \mathrm{N}, 60 \mathrm{Kg} \mathrm{P}_{2} \mathrm{O}_{5}$ and $60 \mathrm{~kg} \mathrm{~K} 2 \mathrm{O} / \mathrm{ha}$. The treatments were replicated four times and laid out in randomized complete block design having plot size $8 \mathrm{~m} \times 8 \mathrm{~m}$. At the time of final land preparation green manure (GM) (Sesbanea aculeata L.), FYM, wheat straw (WS) and entire phosphatic and potassic fertilizers along with $50 \%$ of $\mathrm{N}$ were applied as basal dose as per treatment. The remaining $50 \% \mathrm{~N}$ was applied with two equal splits one at tillering and another at panicle initiation stage. One portion of the collected soil samples was air-dried, ground, and sieved to pass through a 4.75-mm sieve and was used for aggregate separation.

\section{Soil analysis}

Aggregate stability of the samples was determined by wet sieving methods following Cambardella and Elliot (1993) [2] taking the sieves of $2,0.25$ and $0.053 \mathrm{~mm}$ sizes. The different aggregate size fractions obtained were large macro-aggregate (> $2.0 \mathrm{~mm})$, small macro-aggregate $(2.0-0.25 \mathrm{~mm})$, microaggregate $(0.25-0.053 \mathrm{~mm})$ and clay + silt $(<0.053 \mathrm{~mm})$. All the aggregate fractions were oven dried at $60{ }^{\circ} \mathrm{C}$ until constant weight. Mean weight diameter (MWD) was calculated from the following equation (Kemper and Koch, 1966) ${ }^{[9]}$ :

$$
\mathrm{MWD}=\sum \mathrm{X}_{\mathrm{i}} * \mathrm{~W}_{\mathrm{i}}
$$

where $\mathrm{Xi}$ was the mean diameter $(\mathrm{mm})$ of the soil aggregate size fractions and $\mathrm{Wi}$ was the proportion of each aggregate size with respect to the total sample weight. The percentage weight of water stable macro-aggregates (WSMA) was determined by the sum of aggregates retained on sieves $>0.25$ mm diameter.

Total soil C (TSC) contents in aggregates were determined by dry combustion method (Nelson and Sommers 1983) ${ }^{[12]}$. Soil inorganic $\mathrm{C}$ (SIC) content was measured by treating the soil with $1 \mathrm{~N} \mathrm{HCl}$ followed by trapping of $\mathrm{CO}_{2}$ by $0.5 \mathrm{~N} \mathrm{NaOH}$ (Snyder and Trofymow 1984) ${ }^{[16]}$. Soil organic C (SOC) was calculated by the difference of TSC and SIC.

The glomalin content of aggregate samples were extracted

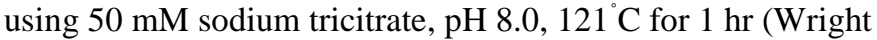
and Upadhyay, 1998) ${ }^{[18]}$. Extraction was repeated until the extractant was straw colored. A modified Bradford protein assay (Wright and Upadhyay, 1996) ${ }^{[19]}$ was used to measure glomalin content in the extract. Samples were diluted with PBS (Phosphate Buffered Saline) and reacted with bio- rad, Bradford protein dye reagent. The intensity of colour was read after $5 \mathrm{~min}$ at $595 \mathrm{~nm}$ in a spectrophotometer. Glomalin content was determined by comparison with a bovine serum albumin (BSA) standard curve.

\section{Statistical analysis}

Experimental data obtained were subjected to analysis of variance (one way ANOVA) in completely randomized block design (RBD) using window based statistical software, SPSS version 16.0. The Duncan's Multiple Range Test at probability $5 \%$ was used to segregate significance of difference among the mean values. The correlation between WSMA, MWD and glomalin associated with aggregates was also done by the same statistical package.

\section{Results and Discussion}

Distribution of soil aggregates: Aggregates distribution, MWD and \% WSMA were significantly affected by longterm application of manures and fertilizers in $0-15 \mathrm{~cm}$ soil depth (Table 1). The MWD, \% WSMA were significantly higher in $\mathrm{T}_{3}(50 \% \mathrm{NPK}+50 \% \mathrm{~N}-\mathrm{FYM})$ compared to other treatments. The MWD was $77 \%$ higher in the $\mathrm{T}_{3}(50 \% \mathrm{NPK}+$ $50 \% \mathrm{~N}-\mathrm{FYM}$ ) than control. Increasing the substitution of $\mathrm{N}$ from 25 to $50 \%$ by organic sources (FYM, WS, GM) resulted in increased aggregate stability as indicated by higher values of MWD and WSMA. All the integrated treatments resulted in a significantly higher value of MWD compared to T2 $(100 \% \mathrm{NPK})$ as well as control. Among the organic sources FYM was superior over WS and GM. The increase in the MWD may be due to the addition of more organic matter under NPK and integrated treatments. Aggregates are stabilized by the forming and strengthening of the bonds between organic matter and clay domains and between quartz particles and clay domains (Emerson, 1977) ${ }^{[5]}$. The addition of organic matter to soil might result in the production of microbial polysaccharides which increases the aggregate stability to mechanical breakdown (Bandyopadhyay et al., 2010) ${ }^{[1]}$. The proportion of micro-aggregates was highest under control and it was decreased with the addition of organic manures and residues because added organic matter helps in the formation of macro-aggregates by binding microaggregates in the soil (Tisdall and Oades, 1982) ${ }^{[17]}$. Application of balanced fertilizers from inorganic and organic sources improved the water stable aggregates were also observed in similar field trials (Hati et al., 2007; Li et al., 2010; Bandyopadhyay et al., 2010; Das et al., 2014) ${ }^{[7,10,1,3] .}$ 
Table 1: Long term effect of manuring and fertilization on aggregate size distribution (\%), mean weight diameter (MWD; mm) and water stable macro aggregates (WSMA; \%) in 0-15 cm soil depth under rice wheat cropping system in Inceptisol

\begin{tabular}{|c|c|c|c|c|c|c|}
\hline \multirow{2}{*}{ Treatments } & \multicolumn{4}{|c|}{ Aggregates (\%) } & \multirow{2}{*}{ MWD (mm) } & \multirow{2}{*}{ WSMA (\%) } \\
\hline & $>2.0 \mathrm{~mm}$ & $2.0-0.250 \mathrm{~mm}$ & $0.250-0.053 \mathrm{~mm}$ & $<0.053 \mathrm{~mm}$ & & \\
\hline Control $\left(\mathrm{T}_{1}\right)$ & $4.62^{f}$ & $20.51^{\mathrm{h}}$ & $71.85^{\mathrm{a}}$ & $3.01^{\mathrm{a}}$ & $0.48^{\mathrm{g}}$ & $25.14^{\mathrm{h}}$ \\
\hline $100 \%$ NPK $\left(\mathrm{T}_{2}\right)$ & $6.79^{\mathrm{e}}$ & $23.26^{\mathrm{g}}$ & $66.86^{\mathrm{b}}$ & $3.08^{\mathrm{a}}$ & $0.57^{\mathrm{f}}$ & $30.05^{\mathrm{g}}$ \\
\hline $50 \% \mathrm{NPK}+50 \% \mathrm{~N}-\mathrm{FYM}\left(\mathrm{T}_{3}\right)$ & $11.06^{\mathrm{a}}$ & $39.44^{\mathrm{a}}$ & $48.49^{\mathrm{g}}$ & $1.02^{\mathrm{d}}$ & $0.85^{\mathrm{a}}$ & $50.49^{a}$ \\
\hline $75 \% \mathrm{NPK}+25 \% \mathrm{~N}-\mathrm{FYM}\left(\mathrm{T}_{4}\right)$ & $7.96^{\mathrm{c}}$ & $30.14^{\mathrm{c}}$ & $60.53^{\mathrm{e}}$ & $1.37^{\mathrm{c}}$ & $0.67^{\mathrm{c}}$ & $38.10^{\mathrm{c}}$ \\
\hline $50 \% \mathrm{NPK}+50 \% \mathrm{~N}-\mathrm{WS}\left(\mathrm{T}_{5}\right)$ & $10.43^{\mathrm{b}}$ & $37.23^{\mathrm{b}}$ & $50.89^{f}$ & $1.44^{\mathrm{c}}$ & $0.81^{\mathrm{b}}$ & $47.66^{\mathrm{b}}$ \\
\hline $75 \% \mathrm{NPK}+25 \% \mathrm{~N}-\mathrm{WS}\left(\mathrm{T}_{6}\right)$ & $7.31^{\mathrm{d}}$ & $28.45^{\mathrm{d}}$ & $62.34^{\mathrm{d}}$ & $1.90^{\mathrm{b}}$ & $0.63^{\mathrm{d}}$ & $35.76^{\mathrm{d}}$ \\
\hline $50 \% \mathrm{NPK}+50 \% \mathrm{~N}-\mathrm{GM}\left(\mathrm{T}_{7}\right)$ & $8.25^{\mathrm{c}}$ & $26.36^{\mathrm{e}}$ & $63.59^{c}$ & $1.80^{\mathrm{b}}$ & $0.64^{\mathrm{d}}$ & $34.61^{\mathrm{e}}$ \\
\hline $75 \% \mathrm{NPK}+25 \% \mathrm{~N}-\mathrm{GM}\left(\mathrm{T}_{8}\right)$ & $7.37^{\mathrm{d}}$ & $24.36^{\mathrm{f}}$ & $66.27^{\mathrm{b}}$ & $2.00^{\mathrm{b}}$ & $0.60^{\mathrm{e}}$ & $31.73^{\mathrm{f}}$ \\
\hline
\end{tabular}

The data followed by different lower case letters in a particular column are significant according to Duncan's Multiple Range Test at $\mathrm{P}=0.05$

\section{Soil organic $\mathrm{C}$ associated with aggregates}

Macro-aggregate associated carbon (MA-C) varied significantly across various treatments in the 0-15 soil depth (Table 2). The MA-C varied from $6.36 \mathrm{~g} \mathrm{~kg}-1$ under control to $9.46 \mathrm{~g} \mathrm{~kg}-1$ under T6 $(75 \% \mathrm{NPK}+25 \% \mathrm{~N}-\mathrm{WS})$. Microaggregate associated carbon (mA-C) varied from $2.45 \mathrm{~g} \mathrm{kg-1}$ under control to $5.55 \mathrm{~g} \mathrm{~kg}-1$ under T6 $(75 \% \mathrm{NPK}+25 \% \mathrm{~N}-$ WS). Treatment T6 (75\% NPK + 25\% N-WS) increased 48.7 and $126 \%$ MA-C and $\mathrm{mA}-\mathrm{C}$ respectively over control. Substitution of $\mathrm{N}$ from 25 to $50 \%$ by FYM or GM significantly increased MA-C and $\mathrm{mA}-\mathrm{C}$ while WS significantly decreased MA-C and mA-C. The SOC concentrations were more in macro-aggregates (MA-C) than the micro-aggregates in all the treatments. Higher accumulation of $\mathrm{C}$ in macro-aggregates could be due to the more biophysical and chemical protection than in microaggregates (Ghosh et al., 2017) ${ }^{[6]}$.

Table 2: Long term effect of manuring and fertilization on SOC associated with macro-aggregates (MA-C) and micro-aggregates $(\mathrm{mA}-\mathrm{C})$ in $0-15 \mathrm{~cm}$ depth under rice-wheat cropping system in Inceptisol

\begin{tabular}{|c|c|c|}
\hline Treatments & MA-C $\left.\mathbf{~ g ~ k g ~}^{-1}\right)$ & $\mathbf{m A - C}\left(\mathbf{g ~ k g}^{-\mathbf{1}}\right)$ \\
\hline Control $\left(\mathrm{T}_{1}\right)$ & $6.36^{\mathrm{g}}$ & $2.45^{\mathrm{g}}$ \\
\hline $100 \% \mathrm{NPK}\left(\mathrm{T}_{2}\right)$ & $8.09^{\mathrm{e}}$ & $4.18^{\mathrm{e}}$ \\
\hline $50 \% \mathrm{NPK}+50 \% \mathrm{~N}-\mathrm{FYM}\left(\mathrm{T}_{3}\right)$ & $7.90^{\mathrm{f}}$ & $3.99^{\mathrm{f}}$ \\
\hline $75 \% \mathrm{NPK}+25 \% \mathrm{~N}-\mathrm{FYM}\left(\mathrm{T}_{4}\right)$ & $8.31^{\mathrm{d}}$ & $4.40^{\mathrm{d}}$ \\
\hline $50 \% \mathrm{NPK}+50 \% \mathrm{~N}-\mathrm{WS}\left(\mathrm{T}_{5}\right)$ & $8.09^{\mathrm{e}}$ & $4.18^{\mathrm{e}}$ \\
\hline $75 \% \mathrm{NPK}+25 \% \mathrm{~N}-\mathrm{WS}\left(\mathrm{T}_{6}\right)$ & $9.46^{\mathrm{a}}$ & $5.55^{\mathrm{a}}$ \\
\hline $50 \% \mathrm{NPK}+50 \% \mathrm{~N}-\mathrm{GM}\left(\mathrm{T}_{7}\right)$ & $8.96^{\mathrm{b}}$ & $5.05^{\mathrm{b}}$ \\
\hline $75 \% \mathrm{NPK}+25 \% \mathrm{~N}-\mathrm{GM}\left(\mathrm{T}_{8}\right)$ & $8.43^{\mathrm{c}}$ & $4.52^{\mathrm{c}}$ \\
\hline
\end{tabular}

The data followed by different lower case letters in a particular column are significant according to Duncan's Multiple Range Test at $\mathrm{P}=0.05$.

\section{Glomalin associated with aggregates}

Glomalin associated with macro-aggregates (GMA) and micro-aggregates (GMI) varied significantly across various treatments in $0-15 \mathrm{~cm}$ soil depth (Table 3 ). The GMA varied from $2.50 \mathrm{mg} \mathrm{g}^{-1}$ under control to $3.50 \mathrm{mg} \mathrm{g}^{-1}$ under $\mathrm{T}_{7}(50 \%$ $\mathrm{NPK}+50 \% \mathrm{~N}-\mathrm{GM})$. The GMI varied from $2.0 \mathrm{mg} \mathrm{g}^{-1}$ under control to $3.12 \mathrm{mg} \mathrm{g}^{-1}$ under $\mathrm{T}_{3}(50 \% \mathrm{NPK}+50 \% \mathrm{~N}$ - FYM). The GMA was higher than GmA in all the treatments indicates that fungal protein plays an important role in the formation of macro-aggregates. MWD is strongly correlated with GMA ( $\left.\mathrm{r}=0.74^{*}\right)$ and $\mathrm{GmA}\left(\mathrm{r}=0.95^{* *}\right)$ (Table 4). Positive role of glomalin in the formation of WSMA was indicated by correlation coefficient.
Table 3: Long term effect of manuring and fertilization on glomalin associated with macro-aggregates (GMA) and micro-aggregates $(\mathrm{GmA})$ in $0-15 \mathrm{~cm}$ depth under rice-wheat cropping system in Inceptisol

\begin{tabular}{|c|c|c|}
\hline Treatments & GMA $\left(\mathbf{m g ~ g}^{-\mathbf{1}}\right)$ & $\mathbf{G m A}\left(\mathbf{m g ~ g}^{-\mathbf{1}}\right)$ \\
\hline Control $\left(\mathrm{T}_{1}\right)$ & $2.50^{\mathrm{e}}$ & $2.00^{\mathrm{g}}$ \\
\hline $100 \% \mathrm{NPK}\left(\mathrm{T}_{2}\right)$ & $2.78^{\mathrm{d}}$ & $2.25^{\mathrm{f}}$ \\
\hline $50 \% \mathrm{NPK}+50 \% \mathrm{~N}-\mathrm{FYM}\left(\mathrm{T}_{3}\right)$ & $3.30^{\mathrm{bc}}$ & $3.12^{\mathrm{a}}$ \\
\hline $75 \% \mathrm{NPK}+25 \% \mathrm{~N}-\mathrm{FYM}\left(\mathrm{T}_{4}\right)$ & $3.34^{\mathrm{b}}$ & $2.59^{\mathrm{d}}$ \\
\hline $50 \% \mathrm{NPK}+50 \% \mathrm{~N}-\mathrm{WS}\left(\mathrm{T}_{5}\right)$ & $3.37^{\mathrm{b}}$ & $2.92^{\mathrm{b}}$ \\
\hline $75 \% \mathrm{NPK}+25 \% \mathrm{~N}-\mathrm{WS}\left(\mathrm{T}_{6}\right)$ & $3.18^{\mathrm{c}}$ & $2.39^{\mathrm{e}}$ \\
\hline $50 \% \mathrm{NPK}+50 \% \mathrm{~N}-\mathrm{GM}\left(\mathrm{T}_{7}\right)$ & $3.50^{\mathrm{a}}$ & $2.74^{\mathrm{c}}$ \\
\hline $75 \% \mathrm{NPK}+25 \% \mathrm{~N}-\mathrm{GM}\left(\mathrm{T}_{8}\right)$ & $2.90^{\mathrm{d}}$ & $2.52^{\mathrm{d}}$ \\
\hline
\end{tabular}

The data followed by different lower case letters in a particular column are significant according to Duncan's Multiple Range Test at $\mathrm{P}=0.05$.

Table 4: Correlation between MWD, WSMA, GMA and GmA under rice-wheat cropping system in Inceptisol

\begin{tabular}{|c|c|c|c|c|}
\hline Parameters & MWD & WSMA & GMA & GmA \\
\hline MWD & 1 & & & \\
\hline WSMA & $0.99 * *$ & 1 & & \\
\hline GMA & $0.74 *$ & $0.73 *$ & 1 & \\
\hline GmA & $0.95 * *$ & $0.93 * *$ & $0.82 *$ & 1 \\
\hline$* *$ Correlation is significant at the 0.01 & level (2-tailed)
\end{tabular}

**. Correlation is significant at the 0.01 level (2-tailed) *. Correlation is significant at the 0.05 level (2-tailed). MWD-mean weight diameter, WSMA-water stable macro-aggregates, GMAglomalin associated with macro-aggregates, GmA-glomalin associated with micro-aggregates.

\section{Conclusions}

The study clearly indicated that long-term application of balanced fertilizer alone or in conjunction with FYM, WS or GM favoured the soil aggregation and $\mathrm{C}$ buildup in the soil. Highest \% WSMA (50.49\%) and MWD (0.85 mm) was resulted under T3 (50\% NPK + 50\% N-FYM) while aggregate associated $\mathrm{C}$ increased by $48.7 \%$ (MA-C) and $126 \%$ (mA-C) respectively under T6 $(75 \% \mathrm{NPK}+25 \% \mathrm{~N}-$ WS) over control. Glomalin content was positively related to the stability of aggregates as indicated by the strong correlation of MWD with GMA $(\mathrm{r}=0.74 *)$ and $\mathrm{GmA}$ $\left(\mathrm{r}=0.95^{* *}\right)$.

\section{Acknowledgement}

We sincerely acknowledge the Indian Council of Agricultural Research and Indian Agricultural Research Institute, New Delhi for financial support and ICAR-AICRP on Integrated Farming System (IFS) Kanpur Centre, Uttar Pradesh for providing assistance in conducting this research. 


\section{References}

1. Bandyopadhyay PK, Saha S, Mani PK, Mandal B. Effect of organic inputs on aggregate associated organic carbon concentration under long-term rice-wheat cropping system. Geoderma 2010;154(3-4):379-86.

2. Cambardella CA, Elliott ET. Methods for physical separation and characterization of soil organic matter fractions. In Soil Structure/Soil Biota Interrelationships 1993, 449-457. Elsevier.

3. Das B, Chakraborty D, Singh VK, Aggarwal P, Singh R, Dwivedi BS, et al. Effect of integrated nutrient management practice on soil aggregate properties, its stability and aggregate-associated carbon content in an intensive rice-wheat system. Soil and Tillage Research 2014;136:9-18.

4. Duiker SW, Rhoton FE, Torrent J, Smeck NE, Lal R. Iron (hydr) oxide crystallinity effects on soil aggregation. Soil Science Society of America Journal 2003;67(2):60611.

5. Emerson WW. Physical properties and structure. In 'Soil factors in crop production in a semi-arid environment'. (Eds JS Russell, EL Greacen) 1977, 78-104. (University of Queensland Press: St. Lucia, Qld)

6. Ghosh A, Bhattacharyya R, Meena MC, Dwivedi BS, Singh G, Agnihotri R, et al. Long-term fertilization effects on soil organic carbon sequestration in an Inceptisol. Soil and Tillage Research 2018;177:134-44.

7. Hati KM, Swarup A, Dwivedi AK, Misra AK, Bandyopadhyay KK. Changes in soil physical properties and organic carbon status at the topsoil horizon of a vertisol of central India after 28 years of continuous cropping, fertilization and manuring. Agriculture, ecosystems \& environment 2007;119(1-2):127-34.

8. Jastrow JD. Soil aggregate formation and the accrual of particulate and mineral-associated organic matter. Soil biology and biochemistry 1996;28(4-5):665-76.

9. Kemper WD, Koch EJ. Aggregate stability of soils from western United States and Canada 1966.

10. Li H, Qiu J, Wang L, Tang H, Li C, Van Ranst E, et al. Modelling impacts of alternative farming management practices on greenhouse gas emissions from a winter wheat-maize rotation system in China. Agriculture, ecosystems \& environment 2010;135(1-2):24-33.

11. Mandal B, Majumder B, Bandyopadhyay PK, Hazra GC, Gangopadhyay A, Samantaray RN, et al. The potential of cropping systems and soil amendments for carbon sequestration in soils under long-term experiments in subtropical India. Global change biology 2007;13(2):35769.

12. Nelson DW, Sommers L. Total carbon, organic carbon, and organic matter. Methods of soil analysis: Part 2 chemical and microbiological properties. 1983; 9:539-79.

13. Sharma PK, Bhushan L. Physical characterization of a soil amended with organic residues in a rice-wheat cropping system using a single value soil physical index. Soil and Tillage Research 2001;60(3-4):143-52.

14. Six J, Elliott ET, Paustian K, Doran JW. Aggregation and soil organic matter accumulation in cultivated and native grassland soils. Soil Science Society of America Journal 1998;62(5):1367-77.

15. Six J, Elliott ET, Paustian K. Aggregate and soil organic matter dynamics under conventional and no-tillage systems. Soil Science Society of America Journal 1999;63(5):1350-8.
16. Snyder JD, Trofymow JA. A rapid accurate wet oxidation diffusion procedure for determining organic and inorganic carbon in plant and soil samples. Communications in Soil Science and Plant Analysis 1984;15(5):587-97.

17. Tisdall JM, Oades J. Organic matter and water-stable aggregates in soils. Journal of soil science 1982;33(2):141-63.

18. Wright SF, Upadhyaya A. A survey of soils for aggregate stability and glomalin, a glycoprotein produced by hyphae of arbuscular mycorrhizal fungi. Plant and soil 1998;198(1):97-107.

19. Wright SF, Upadhyaya A. Extraction of an abundant and unusual protein from soil and comparison with hyphal protein of arbuscular mycorrhizal fungi. Soil science 1996;161(9):575-86. 